Eur J Clin Chem Clin Biochem

1995; 33:743-748

(c) 1995 Walter de Gruyter \& Co. Berlin - New York

\title{
Measurement of S-100 Protein in Human Blood and Cerebrospinal Fluid: Analytical Method and Preliminary Clinical Results
}

\author{
By Ulrich Missler ${ }^{1}$ and Martin Wiesmann ${ }^{2}$ \\ 1 Neuroradiologie am Institut für Radiologie der Medizinischen Universität zu Lübeck, Lübeck, Germany \\ 2 Klinik für Neurochirurgie der Medizinischen Universität zu Lübeck, Lübeck, Germany
}

(Received March 17/June 27, 1995)

Summary: An immunofluorometric sandwich assay for determination of S-100 protein in cerebrospinal fluid (CSF) and blood is described. The lower detection limit was $0.015 \mu \mathrm{g} / 1$ of S-100 protein. Intra-assay and inter-assay imprecision (coefficients of variation, CVs) were 2.1 to $3.2 \%$ and 7.8 to $11.6 \%$, respectively. S-100 protein recovery in cerebrospinal fluid was 94 to $103 \%$. In blood the recovery varied from 67 to $96 \%$, depending on blood samples used and the concentration of S-100 protein. The best recovery in blood was found using heparinized plasma. In healthy subjects $0.098 \pm 0.11 \mu \mathrm{g} / 1$ (mean $\pm \mathrm{SD}$ ) of $\mathrm{S}-100$ protein was detected $(n=30)$. In the CSF of otherwise healthy patients undergoing a myelography for lumbar pain $1.43 \pm 0.49 \mu \mathrm{g} / 1$ (mean $\pm \mathrm{SD}$ ) of S-100 protein was found. Preliminary results from longitudinal studies on S-100 protein in neurosurgical patients indicate a positive correlation between S-100 protein blood levels and clinical course. Thus, the determination of S-100 protein in blood appears to be helpful in the monitoring of patients with neuronal damage.

\section{Introduction}

Every physician involved in the care of neurologically diseased patients in intensive care medicine faces the problem of evaluating patients in coma or under general anaesthesia. In many of these cases, classical neurological examination alone does not allow sufficient monitoring on the intensive care unit for therapeutic guidance or allow early diagnosis of complications. Even computed tomography (CT) and nuclear magnetic resonance (NMR) imaging are not always able to differentiate oedema from structurally damaged neuronal tissue. This is especially true in the acute phase of brain damage. In addition, neuroradiological techniques are expensive and require transportation, which is not without risk for critically ill patients. Monitoring of intracranial pressure, electroencephalogram (EEG) or sensory evoked response are valuable tools and can provide important information but do not prove neuronal destruction. In addition, in intensive care units these methods may be susceptible to technical interference. There is evidence, however, that cerebrospinal fluid markers such as S-100 protein, glial fibrillary acidic protein, neuron-specific enolase and myelin basic protein may serve as quantitative markers of the extent of brain damage.

The term "S-100" refers to a mixture of dimeric proteins consisting of two subunits of $M_{r} 10500$ termed $\alpha$ and $\beta$ (1). Three isoforms are known. $S-100_{a}(\alpha \beta)$ is found in glial cells and melanocytes. $S-100_{b}(\beta \beta)$ is present in high concentration in glial cells and Schwann cells of the central and peripheral nervous system as well as in Langerhans cells and cells of the anterior pituitary. S$100_{\mathrm{ao}}(\alpha \alpha)$ which represents $5 \%$ of the S-100 protein population in brain is found outside the nervous system in slow-twitch muscle, heart and kidney (2). The S-100 protein family constitutes a subgroup of $\mathrm{Ca}^{2+}$-binding proteins of the EF-hand type (3). Apart from calcium they can also bind zinc. Both intracellular and extracellular mechanisms of action have been proposed for S100 protein, although its biological functions are not yet understood in detail (3). S-100 protein is stable in CSF for 2 days at $4{ }^{\circ} \mathrm{C}(4)$.

Several studies on patients with neurological lesions have shown a relationship between cell damage in the 
central nervous system and the concentration of S-100 protein in cerebrospinal fluid (CSF) $(5-13)$. However, especially in patients with substantial lesions of the brain (large tumour, infarction, intracerebral or subarachnoid haemorrhage, neurotrauma) intracranial pressure may be increased and lumbar puncture is contraindicated due to the risk of transtentorial herniation. CSF can be obtained by cannulation of the lateral ventricles. This is, however, not without risk and during cannulation nervous tissue will be damaged, which may distort measurements $(14,15)$.

For these reasons, substances which are released from brain cells during brain damage must be detectable in blood if they are to serve as a useful tool in clinical medicine. In contrast to CSF, however, studies on S-100 protein levels in blood are rare (9). A correlation between S-100 protein levels in blood and damage of the nervous system has not previously been reported. We describe a method for quantifying S-100 protein concentrations in blood and CSF and report the first clinical results obtained with the assay under routine conditions.

\section{Materials and Methods}

\section{Samples}

\section{Reference population}

CSF was obtained from 53 patients ( 25 male, 28 female) aged 1776 years $(55.2 \pm 14.2$, mean $\pm S D)$ who underwent myelography for lumbar pain. Medical history and neurological evaluation revealed no evidence for organic nervous disease. Total protein concentration and cell count in CSF specimens were both normal. Serum and heparinized plasma samples (ammonium heparin, 15 $\left.\times 10^{3} \mathrm{IU} / \mathrm{l}\right)$ were obtained from 30 healthy subjects ( 15 male, 15 female) aged $21-52$ years $(32.5 \pm 7.7$, mean $\pm S D)$.

\section{Neurosurgical patients}

Heparinized plasma and, if available, CSF samples from lumbar punctures, lumbar catheters and lateral ventricle cannulations were obtained for routine analysis from patients of the neurosurgical intensive care unit of the Medical University of Lübeck.

CSF samples from lateral ventricle cannulation of four patients were selected for dilution and analytical recovery experiments. Eleven serum and heparinized plasma samples of healthy subjects were selected for the calcium dependency experiments, and a further 12 samples for dilution studies. All dilutions were made in horse serum (Gibco, Eggenstein, Germany). All blood CSF samples were centrifuged within three hours and the supernatant stored in aliquots of $500 \mu \mathrm{l}$ at $-70^{\circ} \mathrm{C}$.

\section{Materials}

All chemicals were obtained from Merck (Darmstadt, Germany) unless stated otherwise. Purified S-100, S- $100_{b}$ and S-100 ao proteins from Sigma (Deisenhofen, Germany) were used for $S-100$ protein subtype cross-reactivity experiments and as calibrator.

\section{Antibodies}

The polyclonal antibody was raised in rabbit with bovine brain $\mathrm{S}$ 100 protein purified by the method of Moore (1) as antigen
(DAKO, Hamburg, Germany). After plasma adsorption the specifity of the antibody was proven by immunoelectrophoresis and enzyme immunoassay. The antibody was labelled with biotin as described previously (16).

\section{Assay procedure}

\section{. 1}

Microtitre plates (Nunc Maxisorp, Roskilde, Denmark) were coated with anti-S100 protein antibody (DAKO) $900 \mathrm{ng} /$ well in $200 \mu \mathrm{l}$ phosphate buffer, $0.05 \mathrm{~mol} / 1, \mathrm{pH} 8.6$ and allowed to stand overnight at $4^{\circ} \mathrm{C}$. After washing the plates twice with $5 \mathrm{ml} /$ well of washing buffer (Tris $0.05 \mathrm{~mol} / \mathrm{l}, \mathrm{NaCl} 0.15 \mathrm{~mol} / /$, Tween $200.1 \mathrm{ml} / 1, \mathrm{pH}$ 7.5) using a Novopath Platewasher (Bio Rad, München, Germany) they were postcoated for 15 minutes with $300 \mu l$ of carbonate buffer $0.05 \mathrm{~mol} / \mathrm{l}$, pH 9.6 containing bovine serum albumin $10 \mathrm{~g} / \mathrm{l}$ (Sigma) and washed again once with washing buffer. The plates were either used fresh, or were stored at $4{ }^{\circ} \mathrm{C}$ with $200 \mu$ coating buffer per well and sealed with microtitre plate sealings (ICN, Eschwege, Germany). The plates could be stored in this way for 12 weeks without loss in immunoreactivity.

All measurements were set up in duplicate at room temperature. Incubations were performed on a microtitre plate shaker (Heidolph, Kehlheim, Germany) at $200 \mathrm{~min}^{-1}$. CSF samples were measured undiluted and after $1: 100$ dilution in horse serum. S-100 protein calibrators, controls, samples $(200 \mu \mathrm{l})$ and $50 \mu \mathrm{l}$ of horse serum (Gibco) with $\mathrm{CaCl}_{2} 25 \mathrm{mmol} / \mathrm{l}$ were added to each well and incubated for 2 hours. Purified S-100a/b $(1+1$, by vol.) in horse serum was used for calibrators and controls. The plates were washed with washing buffer three times, and $200 \mu \mathrm{l}$ of biotin-labelled anti S100 protein antibody diluted to a final concentration of $2 \mu \mathrm{g} / 1$ in a Tris $0.05 \mathrm{~mol} / \mathrm{l}, \mathrm{NaCl} 0.15 \mathrm{~mol} / \mathrm{l}, \mathrm{CaCl}_{2} 10 \mathrm{mmol} / \mathrm{l}, \mathrm{NaN}_{3} 0.15$ $\mathrm{mmol} / \mathrm{l}$ buffer containing horse serum, volume fraction 0.5 , was added and incubated for one hour.

The plates were again washed three times with washing buffer, after which $200 \mu \mathrm{l}$ of streptavidin-europium were added to each well and incubated for 30 minutes. Streptavidin was labelled as recommended by Pharmacia (Uppsala, Sweden) using their europium-labelling-reagent, and then diluted to a final concentration of $0.025 \mathrm{mg} / \mathrm{l}$ in Tris $0.05 \mathrm{~mol} / \mathrm{NaCl} 0.15 \mathrm{~mol} / 1, \mathrm{NaN}_{3} 0.15 \mathrm{mmol} / \mathrm{l}$, diethylenetriaminopentaacetic acid $0.02 \mathrm{mmol} / \mathrm{l}$, bovine serum albumin $5 \mathrm{~g} / 1$ and bovine $\gamma$-globulin $0.5 \mathrm{~g} / 1$ (Sigma), $\mathrm{pH}$ 7.5. The plates were washed again three times with washing buffer. Enhancement solution $(200 \mu \mathrm{l} /$ well; acetic acid $0.01 \mathrm{~mol} / 1$, tri-n-octyl phosphine oxide $38 \mathrm{mg} / \mathrm{l}$, potassium phthalate $1.3 \mathrm{~g} / \mathrm{l}$, thenoyltrifluoroacetone $222 \mathrm{mg} / \mathrm{l}$, Triton X-100 $2 \mathrm{~mol} / \mathrm{l}$ ) was incubated for 15 minutes. The resulting fluorescence was measured in the DELFIA 1232 fluorometer (Pharmacia). The calibration curve was constructed using a modified spline function in the FIA-Calc data reduction program of the DELFIA 1232 system after a $\log / \log$ transformation of the data.

\section{Effect of calcium concentration on the S-100 protein assay}

To evaluate the effect of calcium concentration on the S-100 protein assay we obtained serum and heparinized plasma samples from 11 healthy subjects. $\mathrm{S}-100_{\mathrm{a} b}\left(1+1\right.$, by vol.) and $\mathrm{CaCl}_{2}$ was added to give final concentrations of 1 and $10 \mu \mathrm{g} / \mathrm{l}$ of $\mathrm{S}-100$ protein and $2,5,10$ and $20 \mathrm{mmol} / 1$ of $\mathrm{CaCl}_{2}$, respectively. For this experiment the buffer solutions described above did not contain calcium.

\section{Results}

\section{Assay characteristics}

A typical calibration curve of the $\mathrm{S}-100$ protein assay is shown in figure 1 . The lower detection limit was 0.015 
$\mu \mathrm{g} / \mathrm{l}(0+3 \mathrm{SD}, \mathrm{n}=24)$ of $\mathrm{S}-100$ protein. The calibration curve ranged from 0.02 to $25 \mu \mathrm{g} / \mathrm{l}$. A high dose "hook"-effect did not occur even at S-100 protein concentrations of $10000 \mu \mathrm{g} / 1$ (fluorescence reading for calibrator $25 \mu \mathrm{g} / \mathrm{l}: 1419080 \mathrm{~s}^{-1}, 10.000 \mu \mathrm{g} / \mathrm{l}: 2483335$ $\mathrm{s}^{-1}$ ). Coated microtitre plates stored in buffer for 3 months at $4{ }^{\circ} \mathrm{C}$ gave the same results as freshly prepared plates. The lower detection limit of the assay depended on the calcium concentration (tab. 1). With increasing $\mathrm{CaCl}_{2}$ concentrations up to $10 \mathrm{mmol} / \mathrm{l}$, the measured $\mathrm{S}$ 100 levels in serum and heparinized plasma of healthy volunteers also steadily increased. Since the best analytical recovery after addition of $\mathrm{S}-100$ protein to blood was achieved with $5 \mathrm{mmol} / 1$ of $\mathrm{CaCl}_{2}$, this calcium concentration was chosen for assay buffers. S-100 protein in heparinized plasma was stable for 24 hours at $20^{\circ} \mathrm{C}$ (10\% loss), for four days at $4{ }^{\circ} \mathrm{C}$ (without loss) and for at least 6 months at $-20^{\circ} \mathrm{C}$. Even four cycles of freezing and thawing did not affect S-100 levels in plasma (data not shown).

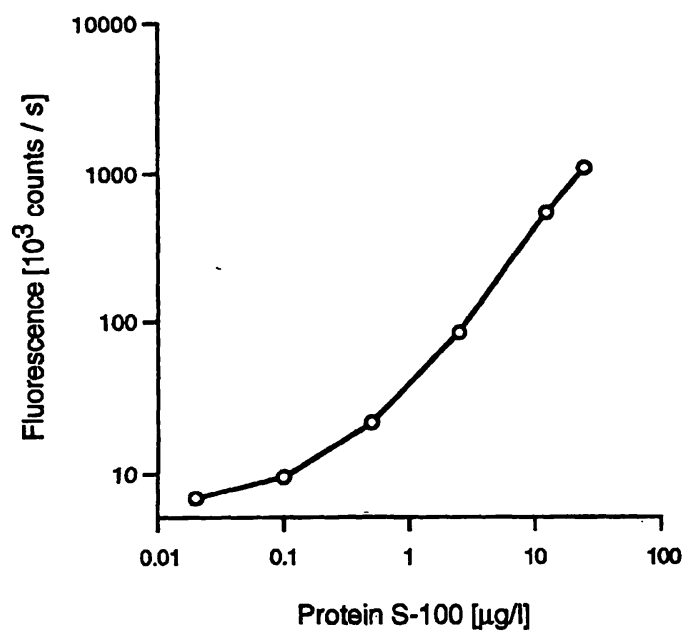

Fig. 1 Typical calibration curve of the S-100 protein assay.

Tab. 1 S-100 protein concentrations in serum and heparinized plasma of 11 healthy subjects after addition of calcium and S-100 protein.

\begin{tabular}{llll}
\hline $\begin{array}{l}\text { Calcium added } \\
{[\mathrm{mmol} / 1]}\end{array}$ & \multicolumn{2}{l}{$\mathrm{S}-100$ protein added $[\mu \mathrm{g} / \mathrm{l}]$} \\
\cline { 2 - 4 } & 0 & 1 & 10 \\
\hline Serum $(\mathrm{n}=11)$ & & & \\
- & $<0.02$ & 0.40 & 4.44 \\
2 & $<0.02$ & 0.51 & 5.11 \\
5 & 0.03 & 0.62 & 6.30 \\
10 & 0.046 & 0.65 & 6.02 \\
& & & \\
Heparinized plasma $(\mathrm{n}=11)$ & & \\
- & 0.063 & 0.76 & 7.97 \\
2 & 0.068 & 0.75 & 7.76 \\
5 & 0.083 & 0.75 & 8.48 \\
10 & 0.092 & 0.66 & 7.30 \\
\hline
\end{tabular}

\section{Precision}

The intra-assay (within-run) imprecision (CVs) was $3.2 \%$ at $0.51 \mu \mathrm{g} / 1,2.1 \%$ at $5.97 \mu \mathrm{g} / \mathrm{l}$, and $2.3 \%$ at 11.4 $\mu \mathrm{g} / \mathrm{l}(\mathrm{n}=20)$. The total imprecision (between-day, CVs) was $11.5 \%$ at $0.45 \mu \mathrm{g} / \mathrm{l}, 7.9 \%$ at $4.79 \mu \mathrm{g} / \mathrm{l}$, and $7.8 \%$ at $15.45 \mu \mathrm{g} / 1(\mathrm{n}=21)$.

\section{S-100 subtype cross reactivity}

The assay detected predominantly $\mathrm{S}-100_{\mathrm{b}}$. Cross reaction by $\mathrm{S}-100$ ao was less than $1 \%$ (tab. 2).

\section{Recovery experiments}

The recovery after mixing different CSF samples varied from $94 \%$ to $103 \%$ (tab. 3). Serial dilution experiments proved the linearity of the assay (figs. 2 and 3 ). The results were different for serum and heparinized plasma (tab. 4).

\section{S-100 protein reference values}

The CSF samples of the reference group contained 1.43 $\pm 0.49 \mu \mathrm{g} / 1$ of S-100 protein (mean $\pm \mathrm{SD}$ ). Values exceeding $2.4 \mu \mathrm{g} / 1$ (mean $+2 \mathrm{SD}$ ) were considered elevated. In the serum of healthy subjects $0.026 \pm 0.057$

Tab. $2100 \mu \mathrm{g} / \mathrm{l}$ of $\mathrm{S}-100_{\mathrm{ao}}, 25 \mu \mathrm{g} / \mathrm{l}$ of $\mathrm{S}-100_{\mathrm{a}}$ and $12,5 \mu \mathrm{g} / \mathrm{l}$ of $\mathrm{S}-100_{\mathrm{b}}$ diluted in horse serum were measured in the $\mathrm{S}-100$ protein assay using $S-100_{a}$ : S-100 as $1+1$ (by vol.) as calibrator. The percentage of cross reactivity was calculated.

\begin{tabular}{|c|c|c|c|}
\hline \multirow{2}{*}{$\begin{array}{l}\text { S-100 protein } \\
\text { subtype }\end{array}$} & \multicolumn{2}{|c|}{ Concentration } & \multirow{2}{*}{$\begin{array}{l}\text { Cross- } \\
\text { reactivity } \\
{[\%]}\end{array}$} \\
\hline & $\begin{array}{l}\text { expected } \\
{[\mu \mathrm{g} / \mathrm{l}]}\end{array}$ & $\begin{array}{l}\text { detected } \\
{[\mu \mathrm{g} / 1]}\end{array}$ & \\
\hline $\begin{array}{l}S-100_{a \circ} \\
S-100_{a} \\
S-100_{b}\end{array}$ & $\begin{array}{l}100 \\
25 \\
12.5\end{array}$ & $\begin{array}{c}0.89 \\
2.91 \\
21.3\end{array}$ & $\begin{array}{c}0.90 \\
12 \\
170\end{array}$ \\
\hline
\end{tabular}

Tab. 3 Four different CSF samples were mixed, measured in the $\mathrm{S}-100$ protein assay and the analytical recovery was calculated as a percentage. The $S-100$ protein concentration of the samples was $20.0 \mu \mathrm{g} / \mathrm{l}$ for specimen $1,0.62 \mu \mathrm{g} / \mathrm{l}$ for specimen $2,4.00 \mu \mathrm{g} / \mathrm{l}$ for specimen 3 and $8.20 \mu \mathrm{g} /$ for specimen 4 .

\begin{tabular}{llll}
\hline $\begin{array}{l}\text { Combination } \\
\text { of specimens }\end{array}$ & \multicolumn{2}{l}{ Concentration } & $\begin{array}{l}\text { Recovery } \\
{[\%]}\end{array}$ \\
\cline { 2 - 3 } & $\begin{array}{l}\text { expected } \\
{[\mu \mathrm{g} / 1]}\end{array}$ & $\begin{array}{l}\text { detected } \\
{[\mu \mathrm{g} / \mathrm{l}]}\end{array}$ & \\
\hline $1+2$ & 10.3 & 10.1 & 98 \\
$1+3$ & 12.0 & 12.0 & 100 \\
$1+4$ & 14.1 & 13.3 & 94 \\
$2+3$ & 2.31 & 2.25 & 97 \\
$2+4$ & 4.41 & 4.40 & 100 \\
$3+4$ & 6.10 & 6.30 & 103 \\
\hline
\end{tabular}


$\mu \mathrm{g} / \mathrm{l}$ of S-100 protein was found (mean $\pm \mathrm{SD}$ ). Concentrations in heparinized plasma $(0.098 \pm 0.11 \mu \mathrm{g} / \mathrm{l}$, mean \pm SD) were nearly four times as high as in serum. Only 6 of the 30 serum reference samples were within the

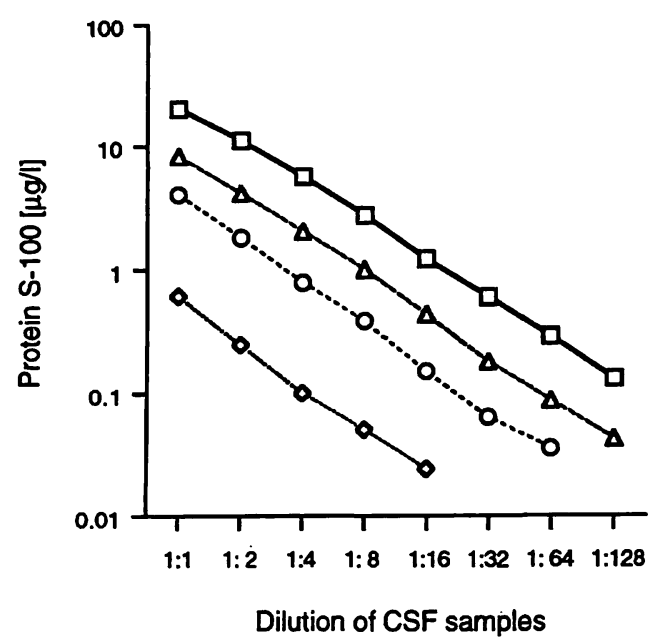

Fig. 2 Serial dilution of four CSF samples in horse serum.

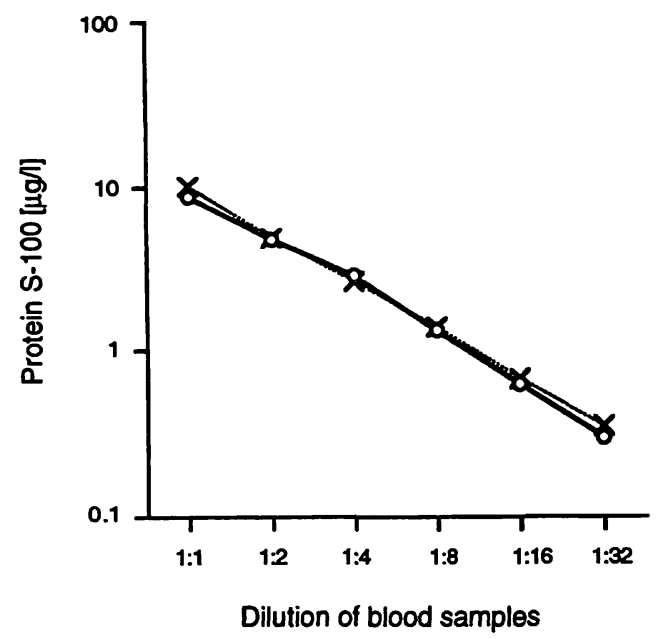

Fig. 3 S-100 protein was added to serum and heparinized plasma of 12 healthy subjects to give a concentration of $10 \mu \mathrm{g} /$. Shown are the mean values of measured $S-100$ protein for serum $(0)$ and heparinized plasma $(x)$ after serial dilution in horse serum.

Tab. 4 Measured concentrations of S-100 protein after addition of 1 and $10 \mu \mathrm{g}$ of S-100 protein to serum and heparinized plasma of 30 healthy subjects. In both incubation steps calcium was added to give a concentration of $5 \mathrm{mmol} / \mathrm{l}$.

Recovery after addition of S-100 protein

$1 \mu \mathrm{g} / \mathrm{l}$ added $\quad 10 \mu \mathrm{g} / \mathrm{l}$ added

Serum

$(\mathrm{n}=30)$

Mean \pm SD

$0.669 \pm 0.47$

$7.20 \pm 1.43$

Heparinized plasma'

$(\mathrm{n}=30)$

Mean $\pm \mathrm{SD}$

$0.775 \pm 0.142$

$9.56 \pm 1.58$ calibration range. In contrast, 22 of the 30 heparinized plasma samples were within the calibration range.

S-100 protein concentrations in blood and CSF were measured during the clinical course in neurosurgical patients. To illustrate the possible diagnostic value of the method described here one individual course of a patient suffering from subarachnoid haemorrhage is presented in figure 4.

\section{Discussion}

Several groups have reported increased cerebrospinal fluid levels of S-100 protein in patients with lesions of the central nervous system (7-13). There is evidence that CSF levels of S-100 protein and other proteins (glial fibrillary acidic protein, neuron-specific enolase) may serve as quantitative markers of the extent of brain damage $(12,15,17-20)$.

In 1987 Persson et al. (9) reported the determination of S-100 protein in CSF and serum, using a radioimmunoassay with rabbit and bovine $\mathrm{S}-100$ protein antibody from DAKO. In the serum of 16 healthy controls they found S-100 protein levels of $\leq 5.3 \mu \mathrm{g} / \mathrm{l}$. In the clinical course of one patient with cerebral infarction they also determined three serum S-100 protein levels within the first 48 hours after onset of symptoms. In this particular case, an increase of S-100 protein levels in blood was demonstrated for the first time. Other reports on S-100

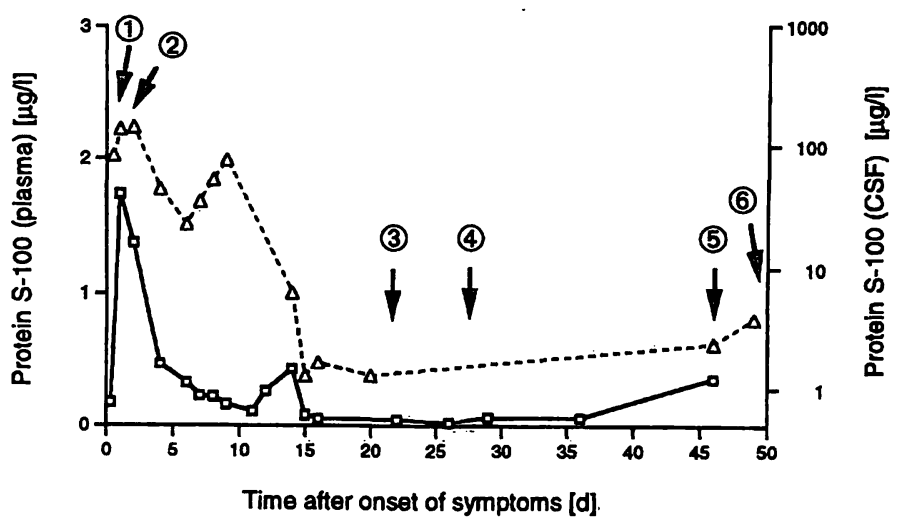

Fig. 4 Plasma $(\square)$ and CSF $(\Delta)$ S-100 protein concentration course from a 42-year old female with a severe subarachnoid haemorrhage with hydrocephalus from a ruptured aneurysm of the anterior communicating artery. Admitted in coma with signs of a tegmental syndrome.

(1) Ventricular cannulation.

(2) Clipping of the aneurysm.

(3) Due to prolonged brain oedema general anaesthesia with barbiturate (methohexital) was performed until day 21 after the operation.

(4) Patient breathed spontaneously. The neurological state improved slowly.

(5) Bacterial meningitis.

(6) Transfer to a rehabilitation unit. At this time she was able to communicate, still suffering from a psychosyndrome. 
protein blood levels in patients with brain damage could not be found in the literature.

The method described measures S-100 protein levels in blood and CSF with adequate sensitivity and reliability. The reference range found for CSF $(\leq 2.4 \mu \mathrm{g} / \mathrm{l})$ corresponds well with the values reported in the literature $(7,13,21)$. Several factors may contribute to the clear differences between the reference values for blood reported by Persson et al. (9) and those reported in the present study. Persson did not describe the calibrator he used. The lower detection limit of their method is $1 \mu \mathrm{g} / \mathrm{l}$, compared with $0.02 \mu \mathrm{g} / 1$ in our assay. Therefore, the main reason may be differences in the calibration. As long as no international standardisation of S-100 protein quantification exists, the comparability of absolute values must remain questionable.

For ethical reasons it is not possible to obtain CSF from healthy volunteers to establish a reference range for normal individuals. Instead we selected patients undergoing myelography for lumbar pain. Neurological examination and medical history revealed no evidence of an organic disease of the central nervous system. Nevertheless this selection remains a compromise. For ethical reasons we also did not obtain ventricular and lumbar CSF simultaneously. Thus we cannot give data concerning the comparability of the two sources. However, Aurell et al. (4) obtained $50 \mathrm{ml}$ of lumbar CSF from patients with normal pressure hydrocephalus in consecutive portions of $10 \mathrm{ml}$ and found no differences in the $\mathrm{S}-100$ protein levels between the five portions.

The effect of calcium on the measurement of S-100 protein has already been described by Sindic et al. (13). We found the same optimal calcium concentration as Sindic et al., and the addition of $5 \mathrm{mmol} / 1 \mathrm{CaCl}_{2}$ decreased the lower detection limit of our assay. Possible explanations of the incomplete recovery of S-100 protein from blood are $S-100$ protein binding proteins, S-100 protein digesting enzymes or poor affinity of the anitbody used. The latter, however, appears unlikely since horse serum was used as diluent for calibrators, controls and all dilutions. Horse serum was also used to dilute CSF, in order to minimize matrix effects (22). Horse serum was used in preference to newborn calf serum, because newborn calf serum contains high levels of S-100 protein which react with the antiserum, particularly since this was raised against bovine $S-100$ protein. To calculate the analytical recovery from CSF a classical mixing experiment was performed. The problem of measuring S-100 protein in blood is the poor recovery rate, which may be the reason why reports on S-100 protein measurements in blood are so rare in the literature. Therefore, we also performed a recovery experiment in which fixed amounts of S-100 protein were added to the serum and heparinized plasma of 30 normal individuals.

Whether decreasing calcium levels during blood coagulation are the only reason for the different recoveries in serum and plasma remains unclear. It is, however, well known from the literature that calcium induces a conformational change in the S-100 protein molecule and thus may affect antibody binding (23). In spite of the fact that calcium is clearly more effective in improving the recovery of S-100 protein from serum, the absolute recovery rates from heparinized plasma remain higher. This may be caused by unknown factors in serum.

Recovery experiments in EDTA and citrate plasma failed, because the addition of calcium induced coagulation. The recovery observed in the experiments to optimize calcium concentration was lower than that obtained later when $5 \mathrm{mmol} / \mathrm{l} \mathrm{CaCl} \mathrm{Cl}_{2}$ was added to all assay buffers.

To assess the clinical importance of the different S-100 protein subtypes $(a, b, a o)$ specific assays must be developed. Our assay predominantly detected S-100 . With reference to the distribution of S-100 protein subtypes described above, this assay appears to be suitable for studying central nervous system disease.

These preliminary results of $\mathrm{S}-100$ protein measurements in neurosurgical patients may indicate a positive correlation between S-100 protein plasma levels and clinical course. In the clinical data shown in figure 4 the course of S-100 protein levels in blood and CSF appears to be similar; the slight differences in blood and CSF may be due to the time-delay caused by the bloodbrain barrier.

In patients with severe polytrauma, $\mathrm{S}-100_{\mathrm{ao}}$ from outside the CNS can influence the results of S-100 protein measurements $(24,25)$. Despite the fact that $S-100_{a o}$ is only detected to less than $1 \%$ with our method, an influence on the results obtained with this assay cannot be completely excluded, although it is unlikely to influence the clinical value of the results.

The assay described above allows a rapid, reliable and non radioisotopic measurement of $\mathrm{S}-100$ protein in blood and CSF. Determination of S-100 protein levels in blood may serve as a useful tool for screening and monitoring patients suffering from lesions of the central nervous system. Assessment of the clinical value of this method will require prospective studies with large patient populations.

\section{Acknowledgements}

We thank $U$. Tietz, U. Hagenström and D. Gottmann for technical assistance and collecting the samples. The helpful advice of Prof. W. G. Wood is gratefully acknowledged. 


\section{References}

1. Moore BW. A soluble protein characteristic of the nervous system. Biochem Biophys Res Commun 1965; 19:739-44.

2. Baudier J, Glasser N, Gerard D. Ions binding to $S 100$ proteins. J Biol Chem 1986; 261:8192-203.

3. Donato R. Perspectives in S-100 protein biology. Cell Calcium 1991; 12:713-26.

4. Aurell A, Rosengren LE, Wikelsø C, Nordberg G, Haglid KG. The S-100 protein in cerebrospinal fluid: a simple ELISA method. J Neurol Sci 1989; 89:157-64.

5. Kato K, Nakajima T, Ishiguro Y, Matsutani T. Sensitive enzyme immunoassay for $\mathrm{S}-100$ protein: determination in human cerebrospinal fluid. Biomed Res 1982; 3:24-8.

6. Michetti F, Massaro A, Russo G, Rigon G. The S-100 antigen in cerebrospinal fluid as a possible index of cell injury in the nervous system. J Neurol Sci 1980; 44:259-63.

7. Mokuno K, Kato K, Kawai K, Matsuoka Y, Yanagi T, Sobue I. Neuron-specific enolase and S-100 protein levels in cerebrospinal fluid of patients with various neurological diseases. $J$ Neurol Sci 1983; 60:443-51.

8. Noppe M, Crols R, Andries D, Lowenthal A. Determination in human cerebrospinal fluid of glial fibrillary acidic protein, S100 and myelin basic protein as indices of non-specific or specific central nervous tissue pathology. Clin Chim Acta 1986; 155:143-50.

9. Persson L, Hårdemark HG, Gustafsson J, Rundström G, Mendel-Hartvit I, Esscher T, Påhlmann S. S-100 protein and neuron-specific enolase in cerebrospinal fluid and serum: markers of cell damage in human central nervous system. Stroke 1987; 18:911-18.

10. Royds JA, Timperley WR, Taylor CB. Levels of enolase and other enzymes in the cerebrospinal fluid as indices of pathological change. J Neurol Neurosurg Psychiatry 1981; 44:1129-35.

11. Strand T, Alling C, Karlsson B, Karlsson I, Winblad B. Brain and plasma proteins in spinal fluid as markers for brain damage and severity of stroke. Stroke 1984; 15:138-44.

12. Rosengren LE, Ahlsén G, Belfrage $M$, Gillberg C, Haglid KG, Hamberger A. A sensitive ELISA for glial fibrillary acidic protein: application in CSF of children. J Neurosci Methods 1992; 44:113-9.

13. Sindic CJM, Chalon MP, Cambiaso CL, Laterre EC, Masson PL. Assessment of damage to the central nervous system by determination of S-100 protein in the cerebrospinal fluid. $J$ Neurol Neurosurg Psychiatry 1982; 45:1130-5.

14. Kruse A, Cesarine KG, Bach FW, Persson L. Increases of neuron-specific enolase, S-100 protein, creatine kinase and creatine kinase BB isoenzyme in CSF following intraventricular catheter implantation. Acta Neurochir (Wien) 1991; 110:106-9.

15. Bach FW, Kruse A, Melgaard B, Børgesen SE. Creatine kinase $\mathrm{BB}$ release into cerebrospinal fluid after lateral ventricle cannulation. Br J Neurolsurg 1988; 2:339-42.

16. Mißler U, Gaida U, Wood WG. Development and evaluation of a time-resolved immunofluorimetric assay for thyrotropin. Eur J Clin Chem Clin Biochem 1993; 31:389-93.

17. Royds JA, Davies-Jones GB, Lewtas NA, Timperley WR, Taylor CB. Enolase isoenzymes in the cerebrospinal fluid of patients with diseases of the central nervous system. J Neurol Neurosurg Psychiatry 1983; 46:1031-6.

18. Hay E, Royds JA, Davies-Jones GB, Lewtas NA, Timperley WR, Taylor CB. Cerebrospinal fluid enolase in stroke. J Neurol Neurosurg Psychiatry 1984; 47:274-9.

19. Hårdemark HG, Persson L, Bolander HG, Hillered L, Olsson Y, Påhlman S. Neuron-specific enolase is a marker of cerebral ischemia and infarct size in rat cerebrospinal fluid. Stroke 1988; 19:1140-4.

20. Takayasu M, Shibuya $M$, Kanamori $M$, Suzuki $Y$, Ogura $K$, Kageyama N, Umekawa $\mathrm{H}$, et al. S-100 protein and calmodulin levels in cerebrospinal fluid after subarachnoid hemorrhage. J Neurosurg 1985; 63:417-20.

21. Van Engelen BGM, Lamers KJB, Gabreels FJM, Wevers RA, van Geel WJA, Borm GF. Age related changes of neuron-specific enolase, S-100 protein, and myelin basic protein concentrations in cerebrospinal fluid. Clin Chem 1992; 38:813-6.

22. Wood WG. Matrix effects in immunoassays. Scand J Clin Invest 1991; 51:105-12.

23. Miles LEM, Lee YL, Eng LF. Calcium ion dependency of the 2-site immunoradiometric assay of Moore's S-100 protein. J Neurochem 1977; 28:1201-5.

24. Usui A, Kato K, Abe T, Murase M, Tanaka M, Takeuchi E. S$100 \mathrm{a}_{0}$ protein in blood and urine during open heart surgery. Clin Chem 1989; 36:1942-4.

25. Usui $A$, Kato $K$, Murase $M$, Hotta T, Tanaka $M$, Takeuchi E, Abe T. Neural tissue-related proteins (NSE, Goa, 28-kDa calbindin-D, S-100b and CK-BB) in serum and cerebrospinal fluid after cardiac arrest. J Neurol Sciences 1994; 123:134-9.

Dr. Ulrich Missler

Institut für Radiologie

Ratzeburger Allee 160

D-23538 Lübeck

Germany 